\title{
Discussão sobre Avaliação Aberta, no âmbito da Ciência Aberta
}

\author{
Milton Shintaku, Ronnie Fagundes de Brito, Rui Seabra Ferreira Jr, Benedito Barraviera
}

\section{PROBLEMA}

um dos aspectos da Ciência Aberta que ainda provocam discussões é a Revisão Aberta pelo Pares (RAP) ou em inglês Open Peer Review (OPR). No Brasil há outro agravante, relacionado a pouca literatura sobre essa modalidade de avaliação.

\section{OBJETIVO}

estudar o processo de avaliação aberta pelos pares, de forma a trazer embasamento teórico voltado ao editor científico, que possibilite a decidir pela adesão ou não desta modalidade.

\section{METODOLOGIA}

"Exploratório

"A principal fonte de coleta foi o google acadêmico

"A busca se deu prioritariamente no idioma inglês
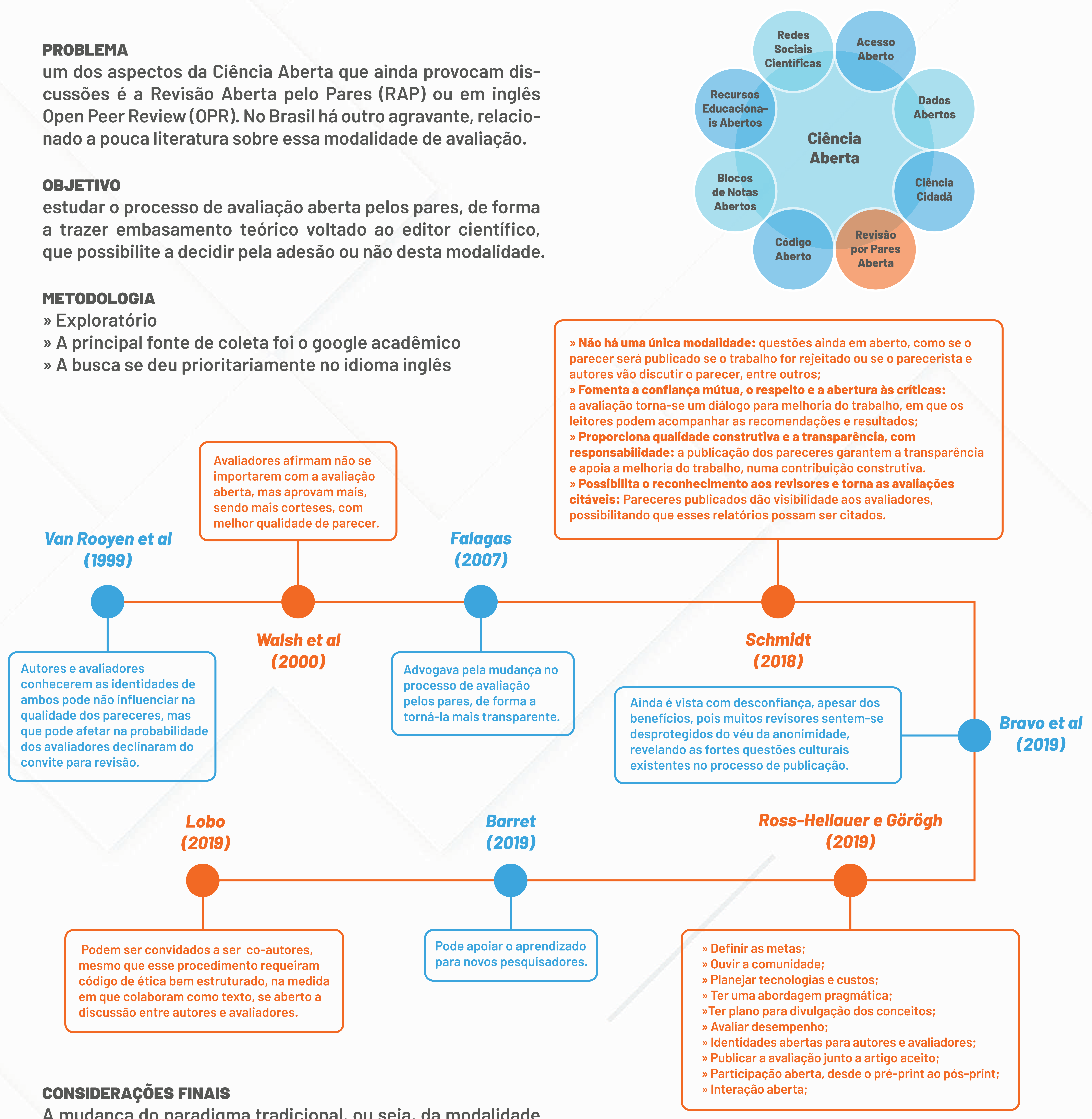

"Não há uma única modalidade: questões ainda em aberto, como se o parecer será publicado se o trabalho for rejeitado ou se o parecerista e autores vão discutir o parecer, entre outros;

") Fomenta a confiança mútua, o respeito e a abertura às críticas: a avaliação torna-se um diálogo para melhoria do trabalho, em que os leitores podem acompanhar as recomendações e resultados; " Proporciona qualidade construtiva e a transparência, com 作 citáveis: Pareceres publicados dão visibilidade aos avaliadores, aberta, mas aprovam mais is corteses, com (1999)

A mudança do paradigma tradicional, ou seja, da modalidade de avaliação fechada para aberta envolve mudanças em processos estabelecidos e aceitos pela comunidade envolvida na publicação científica. Com isso, pode trazer desconfianças que pode acometer a adesão, requerendo ações proativas dos Editores, de forma a produzir um ambiente favorável a implementação do RAP. 